\title{
Islam dalam Demokrasi Bangladesh
}

\author{
M. Azizzullah Ilyas \\ Institut Agama Islam Negeri (IAIN) Bengkulu, Indonesia \\ alcurufi@gmail.com
}

\begin{abstract}
Islämic teachings believed by some to be inseparable from the life of Islämic society, including in-state life which makes democracy a political method complete with party systems but issues heard in Bangladesh that also uses the political method of democracy in the state, parties that embrace Islämic ideology a difficult problem was even declared a band party. This study aims to see, analyze with a descriptive approach with library data sources to see the facts that occur, the role of Islamic parties and find patterns of an Islämic party in Bangladesh, especially the JIB party (Jamaat Islamiyah Bangladesh) in democracy. The results of the study found that Bangladesh, including Flawed Democracy and the Bangladeshi regime, made the reasons for terrorism and history a pretext to suppress the Islämic party which is also an opposition government party, especially JIB, which is a fusion of the Bangladesh Muslim League and Islämic Democratic League. But despite the party's forbidden right-wing but has alliances with other major parties such as the BNP and Awami League and JIB still articulates through the mouthpiece of secular parties, even the voice of Islamic parties remains the key to $B N P$ victory in elections.
\end{abstract}

Keywords: Bangladesh; JIB; Democracy

\begin{abstract}
Abstrak
Ajaran Islam diyakini oleh beberapa kalangan tidak dapat dipisahkan dari kehidupan masyarakat Islam, termasuk dalam kehidupan bernegara yang menjadikan demokrasi sebagai metode politik lengkap dengan sistem kepartaiannya namun isu yang terdengar di negara Bangladesh yang juga menggunakan metode politik demokrasi dalam bernegara, partai yang menganut ideologi Islam menghadapi persoalan yang pelik bahkan dinyatakan sebagai partai terlarang. Penelitian ini bertujuan melihat, menganalisa dengan pendekatan deskriptif dengan sumber data kepustakaan untuk melihat fakta yang terjadi, peranan partai Islam dan menemukan pola partai Islam Bangladesh khususnya partai JIB (Jamaat Islamiyah Bangladesh) dalam berdemokrasi. Hasil penelitian menemukan Bangladesh termasuk flawed Democracy dan rezim Bangladesh menjadikan alasan terorisme dan sejarah masa lalu sebagai dalih untuk memberangus partai Islam yang juga merupakan partai oposisi pemerintahan khususnya JIB yang merupakan fusi dari Bangladesh Muslim League dan Islamic Democratic League. Namun meskipun
\end{abstract}

FOKUS : Jurnal Kajian Keislaman dan Kemasyarakatan Vol. 4, No. 1, 2019 LPPM Institut Agama Islam Negeri (IAIN) Curup - Bengkulu Available online: http://journal.staincurup.ac.id/index.php/JF p-ISSN 2548-334X, e-ISSN 2548-3358 
terlarang sayap kanan partai ini tetapi memiliki aliansi dengan partai-partai besar lain seperti BNP dan Liga Awami dan JIB tetap berartikulasi melalui corong partaipartai sekuler, bahkan suara partai Islam tetap menjadi kunci kemenangan BNP dalam pemilu.

Kata kunci: Bangladesh; JIB; Demokrasi

\section{PENDAHULUAN}

Demokrasi masih tetap menjadi topik yang hangat dalam diskusi perkembangan negara-negara, terkhusus negara yang mayoritas penduduknya beragama Islam. Penerapan demokrasi pada negara seakan menjadi syarat mutlak bagi suatu negara untuk dapat dikatakan maju dan menjunjung nilai-nilai kemanusiaan.

Demokrasi di negara-negara berpenduduk mayoritas Islam mengalami proses perkembangan yang berbeda dengan negara-negara yang penduduknya bukan mayoritas Islam. Dalam prakteknya, tiap-tiap negara memiliki karakteristik tersendiri dalam transisi dan model demokrasi yang diterapkan, demokrasi di Indonesia tentu berbeda dengan demokrasi di Bangladesh hingga tantangan dan persoalan yang dihadapi dalam penerapannya juga berbeda-beda.

Isu demokrasi seringkali digunakan untuk menyudutkan suatu negara, seperti yang banyak ditemukan dalam jurnal-jurnal demokrasi. Diantaranya pandangan K Kinzelbach, peneliti Global Public Policy Institute (GPPI) yang bermarkas di Berlin Jerman, ia menyatakan tanpa demokrasi, tidak ada hak asasi manusia dan tidak ada perdamaian. ${ }^{1}$ Padahal perlu diakui bahwa terdapat unsur yang berbeda yang dimiliki tiap bangsa untuk mendefenisikan demokrasi sesuai dengan kearifan dan nilai-nilai sosial-budaya yang mereka miliki. Pada perkembangannya demokrasi terkonstruksi pada negara-negara dengan sejarah dan perjalanan yang beragam.

Terdapat beragam pendapat yang diajukan dalam mendefenisikan demokrasi. Secara harfiah kata demokrasi berasal dari bahasa Yunani

\footnotetext{
${ }^{1}$ https://www.gppi.net/2017/01/24/without-democracy-no-human-rigt-and-no-peace
} 
Demos yang berarti rakyat dan kretos yang berarti pemerintahan. Yang jargonya familiar ditelinga kita "dari rakyat, oleh rakyat dan untuk rakyat".

Dalam beberapa pendapat dinyatakan bahwa demokrasi berasal dari peradaban Yunani kuno 500 tahun SM. Chelistenes tokoh yang pada masa itu dianggap berjasa banyak dalam pengembangan demokrasi. Di Barat Magna Charta dianggap sebagai jalan pembuka munculnya demokrasi di Barat, yang makin pesat setelah kebangkitan Eropa pada abad pencerahan. Pada masa itu, muncullah sejumlah tokoh seperti John Locke dan Montesquiue. ${ }^{2}$

Lechmann menjelaskan demokrasi sebagai suatu metode politik, suatu mekanisme yang digunakan untuk memilih pemimpin. Tiap warga negara diberikan kesempatan yang sama untuk memilih pemimpin yang bersaing tersebut. ${ }^{3}$ Apabila kebebasan memilih pemimpin dijadikan batasan untuk mendefinisikan demokrasi, maka cara memilih pemimpin dapat disesuaikan dengan kearifan dan kebijaksanaan masing-masing bangsa.

Pendapat lain mengenai demokrasi meminjam apa yang dikemukakan Amin Rais yang menyatakan bahwa sistem demokrasi tidak dapat digambarkan sebagai institusi formal dalam struktur negara, seperti DPR, Partai Politik, Pemilihan Umum, tetapi akan lebih tepat bila dilihat secara substansial. Ada beberapa sistem politik yang nampak seolah-olah demokrasi tetapi sesungguhnya anti demokrasi. Oleh sebab itu, menurutnya memahami demokrasi lebih tepat dari kriterianya daripada mendefinisikannya.

Masyarakat Islam memiliki pandangan dan pemahaman beragam mengenai praktek-praktek dalam agamanya. Hal ini dipengaruhi oleh mazhab serta aqidah dalam beragama. Dimana pada beberapa kesempatan muslim sering disudutkan sebagai masyarakat yang anti "demokrasi".

\footnotetext{
${ }^{2}$ Wajdi, Farid dan Shiddiq. Ilusi Negara Demokrasi. Bogor: Al Azhar Press. 2009., hal. 8

${ }^{3}$ Lechmann, David. Democracy and Development in Latin America, Cambridge: Polity Press, 1989., hal. 67.
} 
Demokrasi yang dimaksud disini adalah demokrasi dengan sistem nilai yang diinginkan Barat, padahal bila ditilik lebih lanjut pemaksaan suatu model demokrasi kepada negara yang memiliki bentuk sosio-kultural yang berbeda tentu akan menimbulkan berbagai gesekan. Yang menjadi pertanyaan bagaimanakah sesungguhnya masyarakat Islam menerapkan demokrasi yang dibangun oleh kearifan mereka sendiri? Dan apakah benar tuduhan-tuduhan yang menyatakan bahwa Islam dan umat Islam tidak menerima demokrasi?

Demokrasi dijunjung tinggi seakan menjadi jaminan keberhasilan sebuah pemerintahan, dan dipandang sebagai satu-satunya bentuk kenegaraan ideal yang memiliki legitimasi etis kedaulatan rakyat, bahwa semua warga negara sama harkat dan hak-hak dasarnya dan dilindungi negara. Pada penelitian yang dilakukan oleh Freedom House menemukan peningkatan jumlah negara yang menerapkan sistem demokrasi dalam pemerintahannya. Pada tahun 1973 hanya sekitar 23\% pemerintahan yang menerapkan sistem demokrasi namun pada tahun 1984 jumlahnya meningkat menjadi $36 \%{ }^{4}$

Sistem demokrasi sekuler yang dianut kebanyakan negara di Eropa dianggap sebagai bentuk ideal dalam perwujudan konsep demokrasi apabila dibandingkan dengan bentuk negara otoriter, namun hal ini tentu akan berbeda bila yang menjadi pembandingnya adalah negara-negara yang maju. Dalam perkembangannya kita sering kali terjebak dalam lingkaran sempit yang mengulang-ulang bahwa sistem politik yang ideal hanya demokrasi saja, dalam beberapa kasus bahkan ditemukan bahwa sistem demokrasi yang diterapkan pada beberapa negara hanyalah seperti trik-trik sulap yang berakhir dengan kegagalan negara dalam mensejahterakan rakyatnya.

Mengkaji kegagalan negara dalam menerapkan demokrasi yang ideal dan sesuai dengan yang dicita-citakan tentu terdapat faktor-faktor yang mempengaruhinya. Terdapat empat pandangan mengenai bagaimana proses demokrasi dalam suatu negara. Pertama, mazhab kesejahteraan,

\footnotetext{
${ }^{4}$ Chumaidy, Chozin. Etika Politik dan Esensi Demokrasi. Jakarta: Pustaka Indonesia Satu. 2006., hal. 8.
} 
menurut mazhab ini ada hubungan yang erat antara meningkatnya ksejahteraan dalam bidang ekonomi dengan terbentuknya pemerintahan yang demokratis. Kedua, mazhab struktur sosial, mazhab ini berpandangan demokrasi baru bisa berjalan dengan baik kalau dalam negara terdapat berbagai macam kelompok sosial yang secara prinsipil sifatnya mandiri. Kelompok sosial itu baik berdasarkan atas kelas, daerah, etnis serta agama. Kelompok-kelompok tersebut memiliki peran untuk membatasi kekuasaan negara sekaligus sebagai kekuatan kontrol. Ketiga, mazhab eksternal. Menurut mazhab ini salah satu pendorong utama bagi timbulnya demokrasi adalah dorongan yang berasal dari luar negara. Sebagai contoh apa yang terjadi pada negara-negara bekas koloni Inggris seperti Malaysia, Singapura, India, dan Bangladesh. Dan keempat, mazhab budaya politik. Menurut mazhab ini budaya masyarakat yang mengandung elemen-elemen demokrasi akan sangat kondusif bagi tumbuh dan berkembangnya suasana demokratis. Prinsip-prinsip demokrasi seperti kesetaraan, kebebasan, keadilan, persatuan dan kesatuan, pertanggung jawaban menjadi suatu sistem nilai dalam masyarakat yang demokratis. ${ }^{5}$ Menjadi kajian bagaimana sesungguhnya negara demokrasi yang ideal, dan apa saja kriteria yang dapat menjadi tolak ukur untuk menentukan keberhasilan demokrasi dalam mensejahterakan penganutnya.

Islam sebagai agama dengan penganut yang terdiri dari multibangsa tentu memiliki pengaruh yang tidak dapat dihilangkan dalam pelaksanaan demokrasi di suatu negara. Freedom House merilis bahwa pada tahun 2007 terdapat 123 negara demokrasi elektoral (naik dari 40 pada tahun 1972). Sedangkan menurut World Forum on Democracy, jumlah negara demokrasi elektoral mencapai 120 dari 192 negara di dunia dan mencakup 58,2 penduduk dunia. Pada saat yang sama, negara-negara demokrasi liberal (yang dianggap Freedom House sebagai negara yang bebas dan menghormati hukum dan HAM) berjumlah 85 dan mencakup

${ }^{5}$ Ibid., hal. 7-8. 
38 persen penduduk dunia ${ }^{6}$. Sedangkan di negara-negara dengan mayoritas penduduk beragama Islam, perkembangan demokrasi mengalami pasang surut, dimana proses demokrasi tetap bergerak lemah, meskipun terjadi gelombang demokrasi baru-baru ini ${ }^{7}$ di negara-negara Timur Tengah.

Berdasarkan penerapan demokrasi, negara-negara dengan penduduk masyoritas muslim dapat dikelompokkan menjadi lima kelompok. Pertama, Kelompok dengan perkembangan demokrasi yang signifikan, seperti Indonesia, Turki dan Malaysia. Kedua, kelompok yang memiliki catatan dalam penerapan demokrasi seperti Pakistan dan Bangladesh yang kemajuan demokrasinya sering dihentikan oleh kudeta militer, namun negara-negara ini tetap memiliki prospek dan potensi untuk menerapkan demokrasi secara ideal. Ketiga, kelompok yang dipimpin oleh rezim, khususnya di dunia Arab; termasuk kedalamnya negara-negara seperti; Maroko, Bahrain, Yordania dan Kuwait, yang meskipun demikian dengan karakter otokratis, mereka mencoba mendesentralisasikan dan meliberalisasi wilayah-wilayah negara tanpa ada kesiapan untuk mendistribusikan kekuasaan dalam pemerintahan ke wilayah-wilayah tersebut. Keempat, negara-negara seperti Arab Saudi, yang hampir stagnan pada posisi otoritatif, tidak menunjukkan adanya celah untuk masuknya demokrasi. Kelima, negara-negara yang berada dalam konflik, seperti Syria, Yaman dan Pelestina dimana masih sangat sulit untuk memprediksikan kemajuan yang signifikan ${ }^{8}$.

Gambaran tersebut memang terlihat lebih suram bila dibandingkan dengan perkembangan demokrasi pada negara-negara non mayoritas muslim, namun tetap memiliki peluang untuk adanya pergerakan kearah demokrasi yang lebih signifikan bila dibandingkan dengan masa-masa sebelumnya.

\footnotetext{
${ }^{6}$ https://jurnalpolitikus.com/2017/12/11/daftar-negara-di-dunia-dengan demokrasipenuh-dan-demokrasi-tidak-sempurna-menurut-democracy-index/ (diakses tanggal 1810-2018)

${ }^{7}$ David Potter. Explaining Democratization in Democratization, ed. David Goldbaltt and others. Cambridge: Polity Press, 1997., hal. 9

${ }^{8}$ Habib Farooq. Democracy in Muslim Word Myth or Reality. NDU Journal. 2009
} 
Namun bila didasarkan oleh apa yang dirilis The Economist Intelligence Unit, negara-negara berpenduduk mayoritas muslim tidak satupun masuk kedalam kategori negara full demokrasi, hanya bertengger pada demokrasi tidak sempurna atau cacat, rezim hibrid, dan rezim otoritarian.

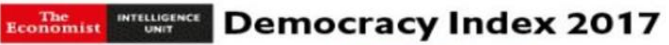

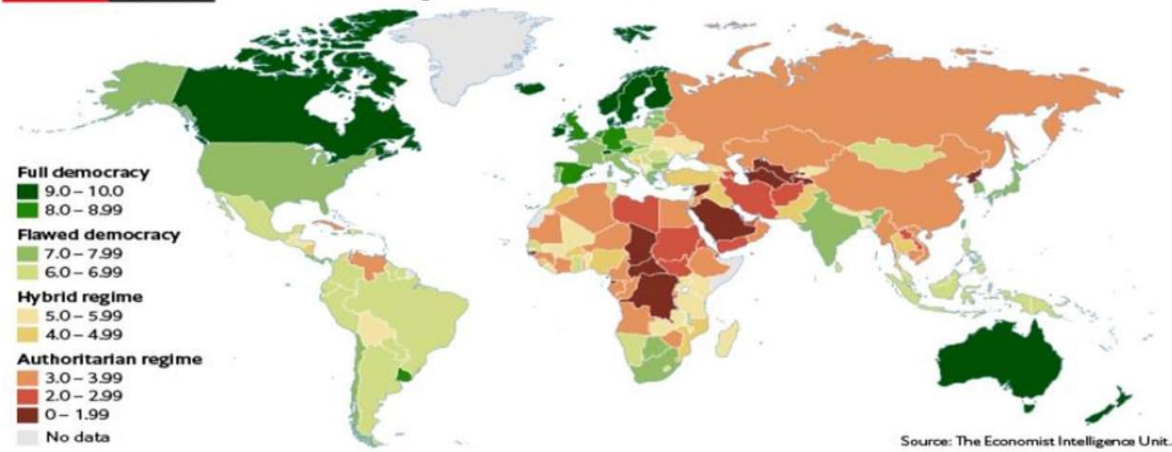

Sumber: The Economist Intelligence Unit

Negara dengan demokrasi penuh adalah negara di mana kebebasan sipil dan kebebasan politik dasar tidak hanya dihormati, tetapi juga diperkuat oleh budaya politik yang kondusif bagi berkembangnya prinsipprinsip demokrasi. Negara-negara ini memiliki sistem checks and balances pemerintah yang valid, peradilan independen yang keputusannya berlaku, pemerintah yang berfungsi secara baik, dan media yang beragam dan independen. Negara-negara ini hanya memiliki masalah terbatas dalam fungsi demokrasi. Selanjutnya, negara dengan demokrasi yang cacat adalah negara-negara di mana pemilu adil dan bebas dan kebebasan sipil dasar dihormati tetapi mungkin memiliki masalah (misalnya pelanggaran kebebasan media). Negara-negara ini memiliki kesalahan signifikan dalam aspek demokratis lainnya, termasuk budaya politik yang belum berkembang, rendahnya tingkat partisipasi dalam politik, dan masalah dalam fungsi pemerintahan.

Sedangkan Rezim hibrida adalah negara-negara yang memiliki masalah dalam pemilihan umum, dimana pemilu tidak dilaksanakan dengan adil dan bebas. Negara-negara ini umumnya memiliki pemerintah 
yang memberikan tekanan pada lawan-lawan politik, lembaga peradilan yang tidak independen, marak korupsi, pelecehan, dan media yang dalam pengawasan dan tekanan, buruknya aturan hukum, dan kesalahan demokrasi begitu terlihat dalam budaya politik yang belum berkembang, rendahnya tingkat partisipasi dalam politik, dan masalah dalam fungsi pemerintahan. ${ }^{9}$

Dapat disimpulkan bahwa untuk mengetahui demokrasi pada suatu negara dapat dilihat lewat proses pemilihan umum, partisipasi politik, fungsi pemerintahan, kebebasan politik dan budaya sipil dalam berdemokrasi

\section{PEMBAHASAN}

Salah satu negara dengan mayoritas penduduknya beragama Islam yang berada pada posisi hybrid rezime adalah Bangladesh. Negera ini pada tahun 2017 berada pada ranking 92 dengan skor 5,43 yang sebelumnya berada pada urutan 84 dengan skor 5,73 di tahun 2016. Penurunan yang dialami oleh Bangladesh juga terjadi pada skor World Justice Project (WJP) pada indeks penerapan hukum. Negara tersebut mengalami penurunan peringkat menjadi 102 dari 113 negara pada tahun 2017-2018. ${ }^{10}$ Hal ini menjadi menarik untuk dikaji lebih lanjut melalui diskursus wacana untuk melihat bagaimana posisi organisasi dan partai muslim terhadap penerapan demokrasi di Bangladesh, peranan dan kontribusinya yang dalam kajian ini diwakili oleh Jamaah Islamiyah sebagai salah satu partai berideologi Islam terbesar di Bangladesh.

\section{Republik Rakyat Bangladesh}

Bangladesh merupakan sebuah negara di Asia Selatan yang berbagi perbatasan darat dengan India dan Myanmar (Burma). Wilayah laut Bangladesh di Teluk Benggala hampir sama dengan luas daratannya.

\footnotetext{
${ }^{9}$ The Economist Intelligence Unit. Democracy Index 2015: Democracy in an age of anxiety $(P D F)$. (diakses 23 Oktober 2018)

${ }^{10} \mathrm{https}: / / \mathrm{www}$.thedailystar.net/frontpage/eiu-democracy-index-bangladesh-slips92th-position-1528165 (diakses pada 18-10-2018)
} 
Bangladesh adalah negara paling padat ke delapan di dunia. Ibu kota Dhaka juga merupakan kota terbesarnya, diikuti oleh Chittagong, yang memiliki pelabuhan terbesar di negara itu. Penduduk Bangladesh terdiri dari berbagai kelompok etnis dan agama. Etnis Bengali yang mayoritas beragama Islam dan berbicara bahasa Bengali membentuk 98\% populasi. Muslim Bengali yang dominan secara politis menjadikan negara ini sebagai negara mayoritas Muslim terbesar ketiga di dunia setelah Indonesia dan Pakistan.

Islam merupakan negara resmi di Bangladesh yang dianut oleh $86 \%$ penduduk, yang mayoritasnya Sunni dan sedikit Syi'ah dan Ahmadiyah. Konstitusi Bangladesh menyatakan Islam sebagai agama negara, tetapi melarang politik berbasis agama. Bangladesh memproklamirkan pengakuan yang sama terhadap umat Hindu, Budha, Kristen dan orangorang yang menganut semua agama. Pada tahun 1972, Bangladesh adalah negara konstitusional sekuler pertama di Asia Tenggara. Yang juga termasuk negara termiskin di dunia.

Bangladesh merdeka pada 16 Desember 1971, yang dibangun diatas prinsip-prinsip sosialis-sekuler. ${ }^{11}$ Dengan sistem parlementer yang dipimpin oleh seorang Perdana Menteri. Pada pemilu 2015 terpilih Sheikh Hasina menjadi Perdana menteri untuk ketiga kalinya, ia merupakan putri dari Sheikh Mujibur Rahman, pendiri Bangladesh. Sebelum menjabat sebagai perdana menteri Syeikh Hasina merupakan presiden dari Liga Awami Bangladesh (BAL) partai politik yang cenderung sekuler. Amerika Serikat, PBB dan negara-negara barat memberikan dukungan besar untuk membentuk dan memperkuat pemerintahan Bangladesh yang demokratis melalui bantuan, teknologi, dan bantuan perdagangan. Barat ingin mempromosikan Bangladesh sebagai model negara Muslim yang menjadikan demokrasi dan Islam bekerja sama dengan baik. ${ }^{12}$

\footnotetext{
${ }^{11}$ Riaz, Ali. Islamist Militancy in Bangladesh: A Complex Web. London: Routledge, 2008., hal. 32

${ }^{12}$ Haass, Richard N. Towards Greater Democracy in the Muslim World. Lecture at the Council on Foreign Relations Washington, DC, 4 December 2002. 2003
} 
Meskipun Islam sebagai agama resmi di Bangladesh, tetapi hukum syari'ah tidak menjadi sumber hukum utama. Namun terdapat beberapa partai yang menjadikan islam sebagai manifesto politik dan dasar ideologi partai. Terdapat tiga organisasi Islam yang berpengaruh di Bangladesh, Jamaat e-Islami Bangladesh yang turut berkontestasi dalam pemilu lewat partai Islamic Democratic League, Hizbut Tahrir Bangladesh (HTB) dan Jamatul Mujahedeen Bangladesh (JMB) yang keduanya mengharamkan pemilu. $^{13}$

Jamaat-e-Islami Bangladesh merupakan cabang dari organisasi yang didirikan oleh Maulana Abul A'la Al-Mauddudi sebelum India pecah pada tahun 1941 menjadi dua negara India dan Pakistan. Jamaat-e-Islami banyak mengambil inspirasi dari Madrasah Darul Ulum Deoband, yang dikenal mempromosikan agama di beberapa wilayah di kawasan tersebut, selain itu Jamaat-e-Islami juga terpengaruh oleh pandangan-pandangan Ikhwanul Muslimin. ${ }^{14}$

\section{Pandangan Demokrasi Maududi}

Untuk memahami pandangan awal Jamaat-e-Islami perlu melihat sikap dan pemikiran pendirinya mengenai demokrasi Abul A'la AlMaududi (1903-1979). ${ }^{15}$ Mengingat misi awal Jamaat-e-Islami didirikan adalah memfokuskan gerakan pada pendidikan dan pengajaran untuk umum, baik dewasa laki-laki dan perempuan pada segala tingkatan dan kelasnya.

Maududi terpilih sebagai ketua Jamaat-e-Islami berturut-turut hingga akhirnya beliau tidak mampu lagi untuk memimpin partai disebabkan oleh sakitnya pada tahun $1972 .{ }^{16}$ Maudidi berpandangan dengan mengumpulkan sekelompok orang yang memiliki visi yang sama dalam

${ }^{13}$ Mubashir, Hasan. Democracy and Political Islam in Bangladesh. South Asia Research Journal, Vol. 31. Issue 3. 2011.

${ }^{14} \mathrm{http} / / / \mathrm{www}$. satp.org/satporgtp/publication/faultlines/volume14/Article1.htm (diakses 18-10-2018)

${ }^{15}$ Ahmad, Khurshid Mawlana Mawdudi: An Introduction to His Life and Thought. Aligarh: Crescent Publishing Co. 1979., hal. 38

${ }^{16}$ Shehadeh, Lamia Rustum. The Idea of Women Under Fundamentalist Islam Gainesville: University Press of Florida, 2003., hal. 23 
satu jamaah akan dapat berpengaruh pada kelompok masyarakat yang lebih besar yang selanjutnya akan dapat mendorong terbentuknya negara Islam. Ketika cikal-bakal negara Pakistan mulai muncul, Al-Maududi pindah ke Lahore dan mulai aktif dalam diskusi-diskusi konstitusi negara baru dan beliau menampilkan dirinya sebagai aktivis yang pro kepada demokrasi, ketika kelompok militer yang sekuler dan berorientasi barat melakukan propaganda-propaganda di masyarakat.

Al-Maududi pernah ditanya sebelum demokrasi diterapkan di Pakistan, apakah demokrasi benar-benar merupakan jalan terbaik ke depan mengingat massa lebih condong kepada kelompok yang anti terhadap gerakan Islam, dan mereka menjanjikan bahwa mereka akan memberikan kebebasan dari kewajiban yang disebabkan oleh agama dan keyakinan. Al-Maudidi menjawab bahwa hati yang telah terikat dengan Islam tidak akan tertarik pada slogan-slogan atas nama makanan dan pakaian. Bahkan di negara-negara Arab ajakan anti Islam hanyalah propaganda belaka. Rasa cinta masyarakat kepada Islam muncul dari hati yang paling dalam. Namun di beberapa negara Arab seperti Syria, Mesir, Iraq, dan beberapa negara Arab Masyarakat tidak diizinkan untuk memilih wakil mereka dalam pemerintahan. ${ }^{17}$

Al-Maududi seakan melihat bahwa melalui demokrasi kondisi yang terjadi di Timur Tengah dalam hak bagi masyarakat dalam memilih wakil mereka dengan bebas dapat dihindarkan. Namun, meskipun demikian nilai-nilai kecintaan kepada Islam yang muncul dari keyakinan beragama tidak akan hilang begitu saja, sehingga demokrasi hanyalah sekedar metode yang digunakan untuk berkompromi dalam dinamika situasi sosial politik .

\section{Jamat e-Islami Bangladesh}

Dalam perkembangannya Jamaat-e-Islami kemudian meluaskan cakupannya dengan mendirikan cabang di Pakistan dan Bangladesh, juga menggunakan nama Jamaat-e-Islami yang disingkat dengan JEL

\footnotetext{
${ }^{17}$ Aijaz, Zakir . Selected Speeches \& Writings of Maulana Maududi, Vol. II. Karachi: International Islamic Publishers. 1982., hal. 151.
} 
Bangladesh yang juga memiliki sayap organisasi mahasiswa Islami Chhatra Shibir (ICS), dimana para anggotanya direkrut dari madrasahmadrasah diwilayah ini.

Perjalanan Jamaat-e-Islami Bangladesh mengalami pasang surut, setelah dituduh memihak Pakistan pada perang tahun 1973 yang berakhir dengan berdirinya Bangladesh sebagai negara yang independen. Jamaate-Islami Bangladesh disahkan pada tahun 1979 sebagai sebagai salah satu partai yang berkontestasi dalam pemilu dengan nama "Islamic Democratic League" setelah keberhasilan coup yang dilakukan oleh kelompok militer dipimpin Jenderal Ziaur Rahman dalam mengulingkan pemerintahan Sheikh Mujibur Rahman. Para pemimpin Jamaat-e-Islami Bangladesh yang sebelumnya diusir keluar negeri kembali pulang ke Bangladesh dan diberikan kesempatan untuk memimpin partai.

Setelah berakhirnya kepemimpinan militer pada tahun 1990 terjadi gerakan protes masa terhadap para pemimpin Jamaat-e-Islami Bangladesh dengan tuduhan kejahatan perang dan terlibat genosida pada periode perang kemerdekaan yang berpengaruh pada perolehan kursi di parlemen pada pemilu 2008.

Meskipun pada tahun 2006 kondisi demokrasi terus memburuk dan memanas tetapi menjadi menarik pada tahun yang sama jumlah partai Islam bermunculan hingga mencapai 100 partai. Namun hanya tujuh partai saja yang terdaftar ikut pemilu; IB, Jaker Party, Khelafot Andolon, Muslim League, Jomiote Ulamaye Islam Bangladesh, Islamic Front Bangladesh and Islami Oikko Jot. Hingga akhirnya di tahun 2008 JIB satu-satunya partai yang bertahan pada pemilu 2008. Namun BAL yang dikenal sebagai partai sekuler memenangi 230 dari 300 kursi. Kondisi ini seakan menunjukan bahwa partai Islam tidak lagi memiliki nilai jual di masyarakat. 
Tabel 1. Perolehan Suara Partai Politik Bangladesh, 1979

(Total Kursi: 300)

\begin{tabular}{|l|c|c|c|}
\hline \multicolumn{1}{|c|}{ Partai } & $\begin{array}{c}\text { Kursi yang } \\
\text { diperebutkan }\end{array}$ & $\begin{array}{c}\text { Perolehan } \\
\text { Kursi }\end{array}$ & Suara \\
\hline Bangladesh Jatiatabadi Dal [BNP] & 298 & 207 & $41.16 \%$ \\
\hline $\begin{array}{l}\text { Bangladesh Awami League } \\
\text { (Malek) }\end{array}$ & 295 & 39 & $24.55 \%$ \\
\hline $\begin{array}{l}\text { Bangladesh Awami League } \\
\text { (Mizan) }\end{array}$ & 184 & 2 & $2.78 \%$ \\
\hline $\begin{array}{l}\text { Bangladesh Muslim League \& } \\
\text { Islamic Democratic League }\end{array}$ & 266 & 20 & $10.08 \%$ \\
\hline $\begin{array}{l}\text { Bangladesh Jatiya Samajtantrik Dal } \\
\text { [JSD] }\end{array}$ & 240 & 8 & $4.84 \%$ \\
\hline National Awami Party (Muzaffar) & 89 & 1 & $2.25 \%$ \\
\hline Bangladesh Gana Front & 46 & 2 & $0.60 \%$ \\
\hline Bangladesh Samayabadi Dal & 20 & 1 & $0.39 \%$ \\
\hline Bangladesh Jatiya League [BJL] & 13 & 2 & $0.36 \%$ \\
\hline Bangladesh Gantantrik Andolan & 5 & 1 & $0.17 \%$ \\
\hline Jatiya Ekota Party & $*$ & 16 & $0.23 \%$ \\
\hline Independent Candidates (422) & 18 & $10.10 \%$ \\
\hline
\end{tabular}

Sumber:(http://www.ecs.gov.bd/English/QLTemplate1.php?Parameter_QLSCat_ID=37) Bangladesh Election Commission Data

Pada tahun 2013 Pengadilan Tinggi Bangladesh memutuskan bahwa JIB merupakan partai ilegal ${ }^{18}$ dan tidak dapat mengikuti pemilihan umum yang akhirnya berujung pada penangkapan dan hukuman gantung presiden Jamaat-e-Islami Bangladesh Matiur Rahman Nizami pada 11 Mei 2016 dengan tuduhan korupsi, terlibat dalam gerakan terorisme ${ }^{19}$ dan kejahatan perang sementara para pemimpin JIB lainnya dipenjara.

\section{Islam, JIB dan Demokrasi di Bangladesh}

Bangladesh bersama Pakistan, Bhutan dan Nepal memiliki record yang tidak terlalu baik dalam demokrasi dibandingkan dengan India dan Srilangka yang merupakan negara dalam satu kawasan. Demokrasi di Bangladesh telah mendapatkan tempat yang signifikan setelah penggulingan rezim militer Irsyad pada 1990 meskipun pemerintahan

${ }^{18} \mathrm{https} / / /$ www.aljazeera.com/news/asia/2013/08/2013819424198348.html (diakses pada $15-10-2018)$

${ }^{19} \mathrm{http} / / / \mathrm{www}$. eurasiareview.com/03022014-bangladesh-court-establishes-bnpjamaat-fountainhead-terrorismanalysis/(diakses pada 15-10-2018) 
militer kembali berulang pada tahun 2007 dan 2008. Tantangan utama dalam proses demokrasi di Bangladesh bahwa situasi politik sangat konfrontatif, khususnya antara dua partai politik utama, Liga Awami dan Partai Nasionalis Bangladesh. Bangladesh juga masih memiliki beberapa jalan dalam mengkonsolidasikan pembangunan demokrasi yang memiliki harapan pada tahun-tahun kedepan. ${ }^{20}$

Setelah terbunuhnya Sheikh Mujibur Rahman presiden pertama Bangladesh pada tahun 1975 yang dalam pemerintahannya memperkenalkan sekularisme sebagai salah satu dari empat prinsip utama dalam konstitusi negara Bangladesh yang notabene berpenduduk mayoritas Islam. Muncul gerakan mempromosikan Islam. melalui ritualritual keagamaan yang mulai dipraktekan dalam acara kenegaraan, madrasah diresmikan, universitas Islam, pembentukan divisi keagamaan dalam kementrian khusus, hingga akhirnya Islam menjadi agama resmi negara pada Juni $1988 .^{21}$

Umat Islam sebagai mayoritas di Bangladesh berperan penting dalam kehidupan bernegara. Demokrasi di Bangladesh terus mengalami perkembangan meskipun menurut beberapa kalangan persoalan utama yang di hadapi Bangladesh adalah kondisi politik yang tidak stabil, ditandai dengan korupsi, kekerasan, nepotisme serta Islam radikal yang mempengaruhi stabilitas perkembangan sosial negara. Gerakan Islam radikal memperoleh dukungan yang cukup signifikan. ${ }^{22}$

Sebagian dari tokoh Islam berpandangan bahwa demokrasi dapat digunakan sebagai jalan untuk menerapkan hukum syariah dalam bernegara, dan demokrasi ala Barat tidak dapat diterima untuk diterapkan

\footnotetext{
${ }^{20}$ Chakma, Bhumitra. South Asia in Transition. England: Pagrave Macmillan. 2014., hal. 14.

${ }^{21}$ Rahim, Enayetur (2001) 'Bengali Muslims and the Islamic Fundamentalism: The Jamat-i-Islami Bangladesh'. In Rafiuddin Ahmed (ed.) New Delhi: Oxford University Press., hal. 248

${ }^{22}$ Hassan, Mubashar. Geopolitics of Political Islam in Bangladesh. Harvard Asia Quarterly Journal. Vol. No. Tahun 2012.
} 
di negara Islam. ${ }^{23}$ Untuk dapat diterima di negara dengan berpenduduk mayoritas muslim yang taat, demokrasi harus dinamis dalam menerima dan mengadopsi unsur-unsur lokal, baik unsur budaya, kearifan dan bahkan agama. Memaksakan bentuk demokrasi liberal yang sekuler di wilayah negara-negara berpenduduk muslim berpotensi besar memunculkan konflik sosial politik.

Pada beberapa negara beragama, demokrasi dapat berkembang dengan baik bersama agama. Islam yang menjadi salah satu agama yang dinamis dan berkemajuan seharusnya dapat lebih memberikan peran dalam kemajuan negara. Namun di beberapa negara, termasuk Bangladesh infilterasi pemahaman radikal telah masuk ke wilayah partai politik Islam terlepas hal ini masih menjadi perdebatan.

Para tokoh kanan Bangladesh menganggap Islam meracuni perkembangan demokrasi, sehingga masuknya unsur agama dalam program lima tahun Bangladesh, berdirinya yayasan agama yang disponsori negara, sekolah-sekolah pemerintah berbasis Islam dianggap sebagai hal memberikan persoalan bagi demokrasi di Bangladesh. ${ }^{24}$

Meskipun Jamaat-e-Islami Bangladesh terlarang, namun sayap kanan partai ini tetap menjalin hubungan serius dengan partai-partai kuat seperti Partai Awami League dan Bangladesh Jatiatabadi Dal (BNP). ${ }^{25}$ Aliansi sayap dari JIB tersebut memberikan pengaruh tersendiri bagi perkembangan demokrasi yang kompleks di Bangladesh.

Menjadi menarik dalam perkembangan demokrasi, meskipun partai khusus yang menjadikan Islam sebagai ideologi telah dilarang, namun partai-partai besar muncul memberikan ruang khusus untuk suara-suara dari kalangan Islam untuk meraup suara. Sehingga kedepannya apabila kondisi tersebut terus berlanjut masyarakat Islam akan tetap memiliki

${ }^{23}$ Esposito, John (ed.) Political Islam: Revolution, Radicalism or Reform. London; Lynne Rienner Publishers. 1997., hal 73

${ }^{24}$ Hassan, Mubashar. Political Islam in Bangladeshi Democracy. East Asia Forum. 2014., hal. 2.

${ }^{25}$ Ibid., hal. 3. 
pengaruh terhadap perkembangan demokrasi dan bersuara melalui wakilwakilnya dalam partai sekuler.

Kondisi ini membuktikan bahwa pihak-pihak dari partai besar tanpa disadari ataupun disadari telah membangun sebuah lingkungan di mana masyarakat Islam dan Islam memberikan pengaruh yang semakin kuat dalam konstelasi demokrasi Bangladesh, mereka membutuhkan dukungan dari kalangan Islam, memberikan wakil mereka tempat. Sebagaimana yang telah terjadi pada masa kepemimpinan militer Jenderal Zia dan Ershad, keduanya mengolah dan menggunakan suara dari kalangan Islam untuk menunjang kelangsungan kekuasaan mereka ${ }^{26}$. Kondisi kembali berulang dimana Islam menyuarakan suara mereka melalui lisan partai sekuler.

JIB meskipun berpandangan bahwa khalifah merupakan hal yang harus diwujudkan, dan setiap keputusan harus dikembalikan ke Al-Qur'an dan Sunnah sebagaimana tercantum dalam konstitusi partai. Partai ini tetap melihat bahwa jalan yang digunakan dalam mencapai tujuan haruslah sistematis, sesuai dengan aturan dan bijaksana. ${ }^{27}$ JIB meyakini bahwa untuk mencapai negara yang sejahtera dapat dicapai melaui demokrasi yang dipimpin oleh mereka yang memiliki komitmen kepada Islam. JIB berkompromi untuk tetap berkiprah dengan aktif sebagai oposisi mesikpun melalui sayap kanan partai yang berafiliasi dengan Partai Nasional Bangladesh.

Perkembangan ini apabila terus berlangsung dapat memberikan sentuhan yang lebih halus bagi jamaat Islami untuk menampilan wajah baru partai Islam yang lebih moderat. Bahkan bukan tidak mungkin partai-partai Islam yang lebih moderat tersebut akan lahir dari rahim partai-partai besar sekuler di Bangladesh.

\footnotetext{
${ }^{26}$ Crisis Group. Restoring Democracy in Bangladesh. Asia Report NO. 151. 2008., hal 31

${ }^{27}$ Hassan. Op. Cit., hal. 108.
} 


\section{PENUTUP}

Islam dan partai Islam akan tetap berada berkontribusi dalam demokrasi Bangladesh dan memiliki kemungkinan besar akan tetap demikian pada masa-masa yang akan datang meskipun kebebasan berserikat umat Islam sangat dibatasi oleh konstitusi sekuler Bangladesh. Untuk tetap bertahan umat Islam Bangladesh harus memiliki suara yang satu untuk dapat tetap berpengaruh dalam perpolitikan Bangladesh. Untuk tetap bertahan Muslim Bangladesh harus memiliki konsep partai yang lebih moderat sehingga dapat berperan dalam kontestasi politik dan perkembangan negara.

Perdebatan dalam Islam mengenai keabsahan dan kehalalan sistem demokrasi merupakan persoalan yang dihadapi pada banyak negara dengan penduduk Muslim. Hizbut Tahrir memberikan banyak saham bagi hilangnya suara dalam setiap pemilihan umum. Namun hal ini tidaklah menjadi suatu hal yang final, tantangan pemahaman mengenai demokrasi yang merupakan alat untuk berkompromi dengan unsur-unsur masyarakat non Islam dan sekuler harus menjadi topik yang membutuhkan pemikiran bijak untuk dijadikan jalan tengah bagi umat Islam untuk mampu bertahan elegan bahkan memimpin di tengah perkembangan zaman tanpa konflik berdarah-darah seperti yang terjadi di beberapa negara di Timur Tengah.

Penelitian ini melihat bahwa isu terorisme dan terfokusnya umat Islam dalam satu partai yang berada di pihak oposisi dapat dijadikan dalih untuk memberangus partai Islam yang sah dan konstitusional dan hal ini dapat dijadikan pembanding bagi perpolitikan di Indonesia.

\section{DAFTAR PUSTAKA}

Ahmad, Khurshid Mawlana Mawdudi: An Introduction to His Life and Thought. Aligarh: Crescent Publishing Co. 1979

Aijaz, Zakir . Selected Speeches \& Writings of Maulana Maududi, Vol. II. Karachi: International Islamic Publishers. 1982 
International Crisis Group. Restoring Democracy in Bangladesh. Asia Report No. 151. 2008

Chumaidy, Chozin. Etika Politik dan Esensi Demokrasi. Jakarta: Pustaka Indonesia Satu. 2006

Chakma, Bhumitra. South Asia in Transition. England: Pagrave Macmillan. 2014

David Potter. Explaining Democratization in Democratization, ed. David Goldbaltt and others. Cambridge: Polity Press, 1997

Esposito, John (ed.) Political Islam: Revolution, Radicalism or Reform. London; Lynne Rienner Publishers. 1997

Haass, Richard N. Towards Greater Democracy in the Muslim World. Lecture at the Council on Foreign Relations Washington, DC, 4 December 2002. 2003

Lechmann, David. Democracy and Development in Latin America, Cambridge: Polity Press, 1989

Rahim, Enayetur. 'Bengali Muslims and the Islamic Fundamentalism: The Jamat-i-Islami Bangladesh'. In Rafiuddin Ahmed (ed.) New Delhi: Oxford University Press. 2001

Riaz, Ali. Islamist Militancy in Bangladesh: A Complex Web. London: Routledge, 2008

Shehadeh, Lamia Rustum. The Idea of Women Under Fundamentalist Islam. Gainesville: University Press of Florida, 2003

Wajdi, Farid dan Shiddiq. Ilusi Negara Demokrasi. Bogor: Al Azhar Press. 2009

Hasan, Mubashir. Democracy and Political Islam in Bangladesh. South Asia Research Journal. Vol. 31. Issue 3. 2011

Hassan, Mubashar. Geopolitics of Political Islam in Bangladesh. Harvard Asia Quarterly Journal. Vol. No. Tahun 2012

The Economist Intelligence Unit. Democracy Index 2015: Democracy in an age of anxiety (PDF). (diakses 23 Oktober 2018)

https://www.thedailystar.net/frontpage/eiu-democracy-index bangladeshslips-92th-position-1528165 (diakses pada 18-10-2018) 
https://jurnalpolitikus.com/2017/12/11/daftar-negara-di-dunia-dengan demokrasi-penuh-dan-demokrasi-tidak-sempurna-menurutdemocracy-index/ (diakses tanggal 18-10-2018)

http://www.satp.org/satporgtp/publication/faultlines/volume14/Article1.ht $\mathrm{m}$ (diakses 18-10-2018)

https://www.aljazeera.com/news/asia/2013/08/2013819424198348.html (diakses pada 15-10-2018)

http://www.eurasiareview.com/03022014-bangladesh-court-establishesbnp-jamaat-fountainhead-terrorismanalysis/(diakses pada 15-102018) 
66| Fokus : Jurnal Kajian Keislaman dan Kemasyarakatan, Vol 4, No. 01, Mei 2019 